\title{
Removal of Hazardous Materials from Residential and Commercial Liquid Waste Using Solid Sorbents
}

\author{
Azmatullah Khan ${ }^{a^{*}}$, Muhammad Habib a , Muhammad Irfan ${ }^{\mathrm{c}}$, Muhammad Akram ${ }^{\mathrm{b}}$, Naik Muhammad ${ }^{\mathrm{a}}$, \\ Nawaz Ali a, Zafar Baloch ${ }^{a}$, Gohram Khan ${ }^{\text {a }}$, Abdul Malik Rehan Abbasi a , Saeeda Yousaf d , Najeeb Ullah a , \\ Mohammad Danish Saleem ${ }^{a}$, Salman Shahid ${ }^{a}$, Muhammad Sanaullah ${ }^{a}$, Zabiullah Khan ${ }^{a}$, Sheharyar Kakar a , \\ Mehrab Malik $^{\text {a }}$ \\ ${ }^{a}$ Faculty of Engineering \& Architecture, Balochistan University of Information Technology, Engineering and \\ Management Sciences, Quetta, Pakistan \\ ${ }^{\mathrm{b}}$ Sungkyunkwan University (SKKU), South Korea \\ ${ }^{c}$ Department of Management Sciences, Balochistan University of Information Technology, Engineering and \\ Management Sciences, Quetta, Pakistan \\ d Department of Environmental Sciences, University of Peshawar
}

${ }^{*}$ Corresponding author's email: azmat.ullah@buitms.edu.pk

\begin{abstract}
Among various pollutants, wastewater consists of toxic or carcinogenic heavy metals such as lead (Pb), zinc ( $\mathrm{Zn})$, and copper $(\mathrm{Cu})$. In this study, the contamination of heavy metals in residential (Domestic) and commercial (Car-wash centre) effluents from urban area of Quetta has been investigated using atomic absorption spectroscopy. The collected liquid effluent was passed through sorbents in vertical flow. The combined batch of Fly ash and Sawdust (adsorbents) showed high sorption capacity $0.0000424 \mathrm{mg} \cdot \mathrm{g}^{-1}$ for lead (residential liquid waste) and $0.0000012 \mathrm{mg} \cdot \mathrm{g}^{-1}$ for $\mathrm{Cu}$ (commercial liquid waste). The moderate partition coefficients were 0.001247 $(\mathrm{Pb})$ and $0.000005(\mathrm{Cu}) \mathrm{mol} \cdot \mathrm{kg}^{-1} \cdot \mathrm{Pa}^{-1}$ for residential and commercial waste respectively. The highest removal efficiency of lead $(99.763 \%)$ for residential effluent showed the breakthrough at $\mathbf{0 . 0 0 2}$. Thus, the sorbents have used significantly high removal efficiency for Pb, moderate for $\mathrm{Zn}$, and low for $\mathrm{Cu}$. The effluent passed from designed filter media may be greatly effective for partial domestic usage i.e., washing, cleaning and irrigation purpose
\end{abstract}

Keywords-Lead; Zinc; Copper; domestic waste; Fly ash; Sawdust

Date Received: 06-10-2020

Date Accepted: 26-10-2020

Date Published: 08-06-2021

\section{T}

\section{INTRODUCTION}

he human activities around the globe have severally affected the quality and quantity of natural resources e.g., fresh water. Every community utilizes water and produces liquid waste also known as wastewater. Wastewater has a source from any combination of domestic industrial, commercial, agricultural, surface runoff, storm water, sewer inflow, and sewer infiltration [1]. Untreated wastewater when discharged to the environment can lead to the emission of anthropogenic gases. Wastewater consist of substantial amount of toxic heavy metals to which human are exposed through various paths [2].

According to the United Nation (UN), it has been observed that a substantial increment $\sim 50 \%$ area has been effected due to untreated wastewater in the last decade [3]. Globally $\sim 80 \%$ of untreated wastewater were discharged into the environment replicated hazardous conditions [4]. According to United Nations (UN) statistical data, $\sim 70$ countries around the globe have non-functional wastewater treatment plan. On the other hand, the local entities consume crops planted on land that is irrigated using untreated wastewater. Five countries i.e., China, Pakistan, India, Mexico, and Iran account for most of these cropland [3]. The current population of Pakistan is $~ 200$ million and is expected to reach $\sim 244$ million by the year 2030 [5]. Pakistan being water stressed would soon become water deficient due to the shortage of water for domestic, industrial and agricultural purposes [6]. 
Fig. 1. Assembly of Material Used for Carwash Sample Treatment.

The contaminated groundwater can be observed in many residential and industrial districts throughout Pakistan. A very less attention has been paid by officials to set the limits for discharge of heavy metals in effluents of carwashes and municipal wastewater. Additionally, the lack of tools to treat the most toxic metals has also been found for effluents such as copper $(\mathrm{Cu})$, lead $(\mathrm{Pb})$, and zinc $(\mathrm{Zn})$ etc. Ultimately, these resulting in environmental degradation due to discharging of heavy metals in the liquid waste. The health hazards of these heavy metals and its permissible limits is shown in the Table I.

TABLE I Permissible Limits and Health Effects of Various Toxic Heavy Metals

\begin{tabular}{|c|c|c|c|c|}
\hline S. No & Metal & $\begin{array}{l}\text { PL for } \\
\text { DW } \\
(\mathrm{mg} \cdot \mathrm{L}-1)\end{array}$ & $\begin{array}{l}\text { MPL for } \\
\text { IW } \\
\text { (ppm) }\end{array}$ & $\begin{array}{l}\text { Health } \\
\text { hazards }\end{array}$ \\
\hline 1 & $\begin{array}{l}\text { Copper } \\
(\mathrm{Cu})\end{array}$ & 2.00 & 0.20 & $\begin{array}{l}\text { Irritation of } \\
\text { nose, mouth, } \\
\text { and eyes, } \\
\text { headache, } \\
\text { stomach- } \\
\text { ache, etc. }\end{array}$ \\
\hline 2 & $\begin{array}{l}\text { Lead } \\
(\mathrm{Pb})\end{array}$ & 0.01 & 0.065 & $\begin{array}{l}\text { Carcinogen, } \\
\text { anaemia, } \\
\text { body pains, } \\
\text { and kidney } \\
\text { problem, etc. }\end{array}$ \\
\hline 3 & $\begin{array}{l}\text { Zinc } \\
(\mathrm{Zn})\end{array}$ & 3.0000 & 0.017 & $\begin{array}{l}\text { Metal fume } \\
\text { fever" and } \\
\text { restlessness, } \\
\text { etc. }\end{array}$ \\
\hline
\end{tabular}

Note: PL (Permissible limit), DW (Drinking water), MPL; Maximum permissible level and IW: Irrigation water [7, 8].

Heavy metals present in drinking water can be perilous to consumers. Heavy metals such as chromium $(\mathrm{Cr})$ and so on can prevent functioning of vital enzymes, effect the calcium found in bones and damage liver. The main source of waterborne toxic chemicals are sewage, agriculture, industrial and radioactive wastes [9]. Agriculturally, Herbicides, Fungicides and other Agro-chemicals significantly contaminates the water resources. Irrigated agriculture is by far the largest consumer of fresh water in Pakistan, however composition for freshwater has increased due to rapidly growing population. Treated wastewater can substitute the use of freshwater in agriculture which is pumped from a very high depth $(\sim 570 \mathrm{~m})$ in Baluchistan [10]. The Quetta being the capital of largest province of Pakistan $(\sim 2.2$ million residents) is the most water deficient city [11]. The use of electric tube wells in Baluchistan is the new norm especially in villages. As a result, the depletion of groundwater level in many regions of Baluchistan is primarily due to the high usage of electric tube wells [12].

The wastewater consists of various types (Table II) of pollutant such as phenolic compounds (amino, Chloro, nitro, and other substituted compounds), different types of pesticides (lindane, Malathion, and carbofuran, etc.) and dyes (methylene blue, crystal violet, malachite green, and etc.). The treatment of wastewater include different technologies and can be divided into three categories i.e., biological, chemical, and physical $[13,14]$.

The aim of this study is to recycle the waste-water (Domestic liquid waste-water and Car wash centre's liquid waste) using the solid sorbent for the removal of heavy metals. The locally available industrial by-products i.e., saw dust and fly ash has been used as adsorbent for an economical research. A comparative study between these two effluents asses the breakthrough profile, partition co-efficient, and sorption capacity. Our study has significance due to isotherm profile exploration for heavy metals in the aqueous phase
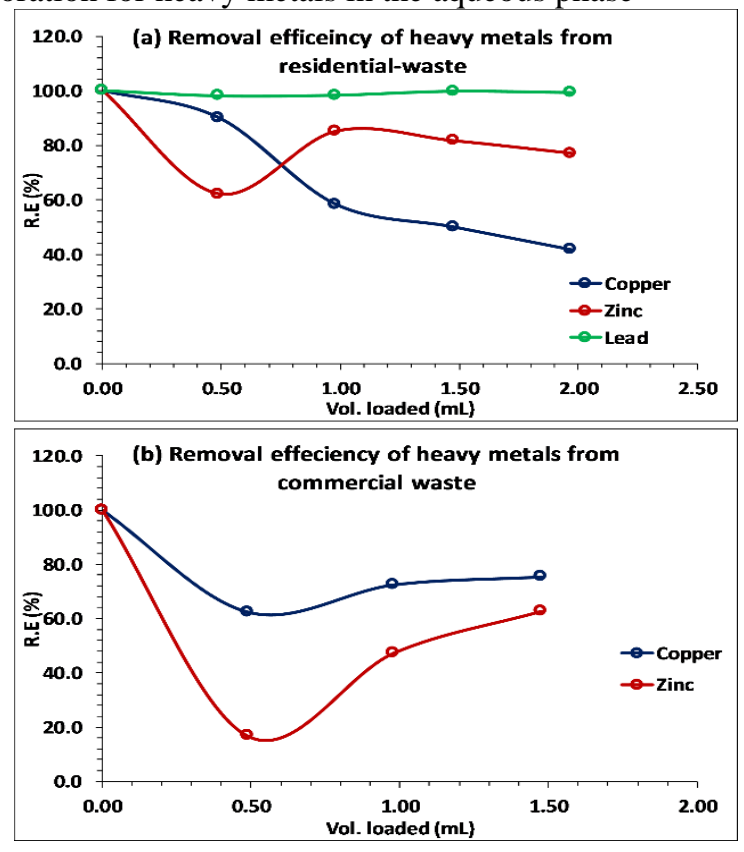

Fig. 2. Removal Efficiency Profile of Sorbent Used for Removal of Heavy Metals.
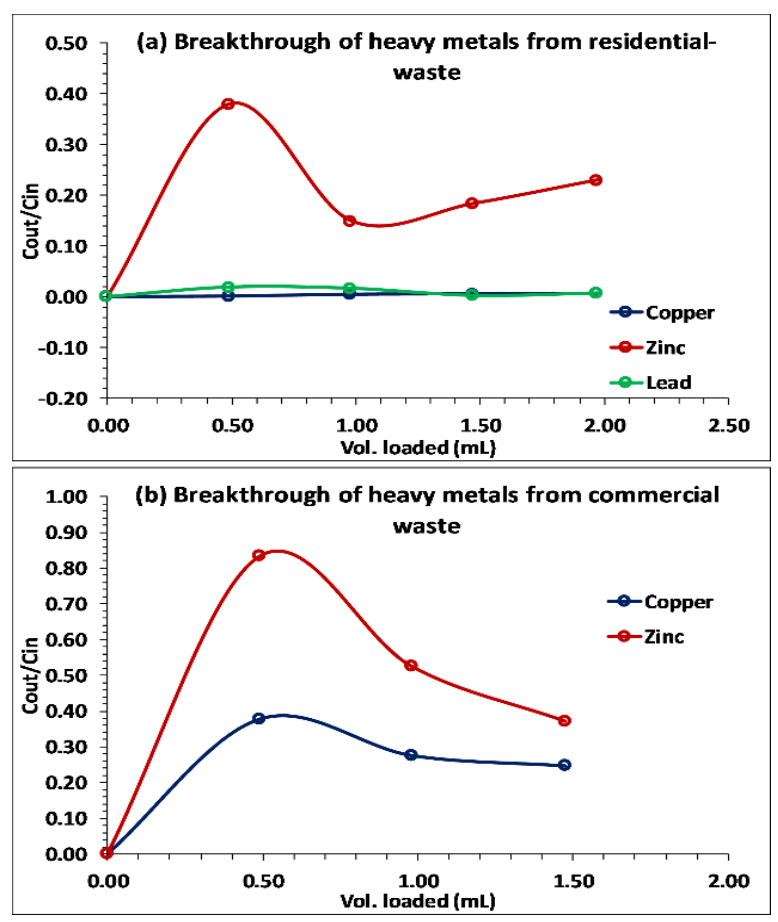
Fig. 3. Breakthrough Profile of Sorbent Used for Removal of Heavy Metals.

\section{MATERIALS AND METHOD USED}

The samples were collected mainly from two sources i.e., car wash centres (Askari Car Wash centre, located in Quetta city) and domestic waste (sewage line of Chiltan sedimentation process to settle down the suspended solids.

The selection Housing Scheme: kitchen + washroom waste). The samples from both the sources were initially treated for of materials was chosen based on the criteria of cost, availability, and expected sorption efficiency. The two major substrates used as Fly Ash and Sawdust with 2:1 mass based. These materials have been found in abundance and at a very affordable price in our vicinity. Fly ash was ordered from Trade-worth International Company Limited Karachi, while Sawdust was sourced from solid waste of Baruri Road, Quetta.

TABLE II Comparison of Wastewater Treatment Technologies Used Previously.

\begin{tabular}{|c|c|c|}
\hline & & \\
\hline Technique & Advantage & Disadvantage \\
\hline $\begin{array}{l}\text { Chemical } \\
\text { Precipitation }\end{array}$ & $\begin{array}{l}\text { Simple, } \\
\text { Inexpensive, }\end{array}$ & $\begin{array}{l}\text { Ineffective for low } \\
\text { conc. Costly, } \\
\text { Produce sludge. }\end{array}$ \\
\hline Ion-exchange & $\begin{array}{l}\text { Useful to heavy } \\
\text { metal removal, I.E } \\
\text { resins can be } \\
\text { regenerated }\end{array}$ & $\begin{array}{l}\text { Produce secondary } \\
\text { pollution, expensive } \\
\text { for treating a large } \\
\text { amount of } \\
\text { wastewater. }\end{array}$ \\
\hline $\begin{array}{l}\text { Membrane } \\
\text { filtration }\end{array}$ & $\begin{array}{l}\text { Highly removes } \\
\text { heavy metal ions } \\
\text { removal efficiency }\end{array}$ & $\begin{array}{l}\text { High cost and } \\
\text { complex process, } \\
\text { limitedly removes } \\
\text { heavy metal. }\end{array}$ \\
\hline $\begin{array}{l}\text { Coagulation, } \\
\text { flocculation }\end{array}$ & $\begin{array}{l}\text { Good sludge } \\
\text { settling and } \\
\text { dewatering } \\
\text { characteristics }\end{array}$ & $\begin{array}{l}\text { Consumes chemical, } \\
\text { increases sludge. }\end{array}$ \\
\hline Flotation & $\begin{array}{l}\text { High metal } \\
\text { selectivity, removal } \\
\text { efficiency, } \\
\text { overflow rates, and } \\
\text { low detention } \\
\text { periods }\end{array}$ & $\begin{array}{l}\text { High initial capital } \\
\text { cost, maintenance, } \\
\text { and operation costs. }\end{array}$ \\
\hline Electrochemical & $\begin{array}{l}\text { Easy controllable, } \\
\text { fewer chemicals, } \\
\text { good reduction } \\
\text { yields, and less } \\
\text { sludge }\end{array}$ & $\begin{array}{l}\text { High initial capital } \\
\text { investment, } \\
\text { expensive electricity } \\
\text { supply. }\end{array}$ \\
\hline Adsorption & $\begin{array}{l}\text { Easy controllable, } \\
\text { useful to remove } \\
\text { heavy metal ions, } \\
\text { and less sludge. }\end{array}$ & $\begin{array}{l}\text { Regeneration of } \\
\text { heavy metals } \\
\text { difficult in liquid } \\
\text { phase, } \\
\text { efficiency depends } \\
\text { adsorbents. }\end{array}$ \\
\hline
\end{tabular}

Reference: [8].
The mass of 20 gm gravel was used to form the first layer so as to retain the sawdust statically in the separating funnel. This layer was tampered using a wooden stick and the phenomenon was repeated for every consecutive layer. Similarly, a $10 \mathrm{gm}$ of sawdust was used as a second layer mainly functioning as major sorbent. In order to preserve the sawdust from suspending into the waste-water, a third layer of gravels (40 gm) was used. Subsequently, a poured $20 \mathrm{gm}$ fly ash (substrate) which accumulated as our fourth layer was used. The last layer of 80 gm gravels serves the purpose of pre-filtration as shown in Fig. 1. Initially, $\sim 3$ min and 16 seconds time required for passing the collected liquid sample the layer of substrates. After min, A $490 \mathrm{~mL}$ of treated sample was collected during 20 minutes. The flow valve was closed for 15 minutes. The 2 nd sample of 490 $\mathrm{mL}$ was collected within $25 \mathrm{~min}$. The same procedure was repeated for sample 3 but collection time for sample 3 was 28 min. For domestic waste-water, first sample took $2 \mathrm{~min}$ and $33 \mathrm{sec}$ to pass through the substrates. After $2 \mathrm{~min}$ and $1420 \mathrm{sec}$, a sample of $490 \mathrm{~mL}$ of treated sample was collected in a collecting container. After 15 minutes, we collected 2nd sample of $495 \mathrm{~mL}$ within $5 \mathrm{~min}$ and $20 \mathrm{sec}$. The same procedure was repeated for sample 3rd and subsequently for 4 th one. The Spectro-analytical procedure has been carried out in a wellestablished laboratory i.e., Pakistan Council of Scientific and Industrial Research (PCSIR).

\section{RESULTS AND DISCUSSIONS:}

\section{A. Removal efficiency}

The raw sample was tested using Atomic absorption spectroscopy at pre-treatment stage i.e., initial concentration of copper $(\mathrm{Cu})$, lead $(\mathrm{Pb})$, and zinc $(\mathrm{Zn})$ in the domestic effluent sample was detected $0.012 \mathrm{ppm}$ and $0.422 \mathrm{ppm}$, and $0.087 \mathrm{ppm}$ respectively. The collected 1st sample showed the removal efficiency (R.E) $98 \%$ for $\mathrm{Pb}$ and $62 \%$ for $\mathrm{Zn}$ metal (Fig. 2a). However, the removal efficiency for eradicating $\mathrm{Cu}$ in 1 st trail was very low. A rare rise was seen in the R.E for 2 nd collected sample which replicated the $\mathrm{Pb}$ for $98.341 \%$, Cu with 58.33\%, and zn with very high value $85.05 \%$. The trend for R.E was then normalized for a classical decreasing tempo with $3 \mathrm{rd}$ and 4 th trail. The R.E was reduced to $99.2 \%$ for $\mathrm{Pb}, 41.66 \%$ for $\mathrm{Cu}$, and $77.01 \% \mathrm{Zn}$. The substrate showed a consistent and strong R.E profile for $\mathrm{Pb}$, followed by $\mathrm{zn}$, and low but considerable for $\mathrm{Cu}$ in domestic waste-water. For car wash samples, the raw sample showed the concentration of $\mathrm{Cu} 0.069 \mathrm{ppm}$ and 0.078 for $\mathrm{Zn}$, while non for $\mathrm{Pb}$. the first collected sample showed the R.E of prepared filter media found with $62.32 \%$ for $\mathrm{Cu}$ and $16.7 \%$ for $\mathrm{Zn}$ (Fig. 2b). The2nd and 3rd trial showed a silly rise in the R.E trend for both metals. The ultimate tempo may the presence of retrograde phenomenon where the partition co-efficient increase instead of decreasing. The same behaviour was found in the gas phase for interaction between VOCs and activated carbon in our previous research [15].

\section{A. Breakthrough profile of the sorbents}

The breakthrough is very essential tool that explore the saturation profile of sorbents-adsorbate interaction used previously [16]. Initially, $\mathrm{Zn}$ showed high saturation for 
breakthrough and then replicated the retrograde behaviour with decreasing the breakthrough for domestic waste-water (Fig. $3 a)$. The classical trend of incremental isotherm was observed from 1.00 to $2.00 \mathrm{~L}$ volume passed. The same breakthrough profile (Retrograde to classical isotherm) was seen for $\mathrm{Pb}$. However, $\mathrm{Cu}$ exhibited almost for a very normal and classical isotherm profile. For car-wash sample (Fig. 3b), both $\mathrm{Cu}$ and $\mathrm{Zn}$ showed a consistent pattern of initial retrograde even up to $1.5 \mathrm{~L}$ liquid volume passed. Due to study limitations, more liquid volume should be pass to see the classical isotherm pattern. However, the sorbent showed strong breakthrough isotherm profile for $\mathrm{Cu}$ compared to $\mathrm{Zn}$. The variation showed in the trend of breakthrough profile may indicates the existence of some chemical functionalities on the sorbent pore surface or other factors [17].
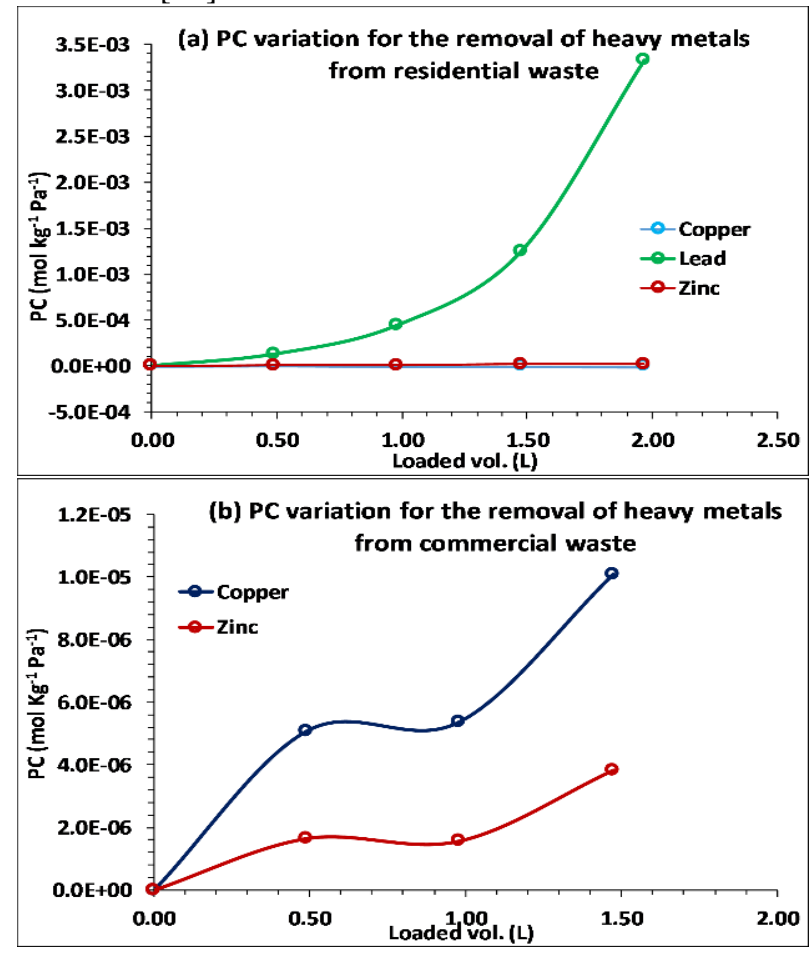

Fig. 4. Partition Co-Efficient Profile of Sorbent Used for Removal of Heavy Metals.

\section{A. Partition co-efficient of sorbents}

The partition co-efficient (PC) is very important parameter the explores the interactive relation between adsorbate and sorbent (liquid to solid in this case. The highest, moderate and lowest partition coefficient values of designed filer media for domestic effluent were observed for $\mathrm{Pb}, \mathrm{Zn}$, and $\mathrm{Cu}$ as 0.003333 , 0.000019 , and $0.000001 \mathrm{~mol} \cdot \cdot \mathrm{kg}^{-1} \cdot \mathrm{Pa}^{-1}$ respectively (Fig. 4a). However, for car wash centre sample (Fig. 4b), the highest and moderate partition coefficient values for $\mathrm{Zn}$ and $\mathrm{Cu}$ were 0.000010 and $0.000002 \mathrm{~mol} \cdot \mathrm{kg}^{-1} \cdot \mathrm{Pa}^{-1}$. The lowest value of partition coefficient for carwash effluents could not be found even passing of 1.6 L of liquid volume. The variation of PC pattern (Retrograde: PC increases with loaded volume) against the Henry's law. Such type isotherm follows the Type-III isotherm where adsorbate interaction with sorbent layer is greater than the interaction with the sorbent surface [18].

\section{B. Adsorption capacity of sorbents}

The adsorption capacity of sorbents is another parameter which illustrates the relationship between the sorbent's capacity $\left(\mathrm{mg} \cdot \mathrm{g}^{-1}\right)$ and loaded volume (L). For domestic effluents, the sorbents showed linear sorption behaviour as the volume loaded of liquid are proportional to the accumulated capacity. The designed filter media shows highest performance for $\mathrm{Pb}$ $\left(0.0000424 \mathrm{mg} \cdot \mathrm{g}^{-1}\right)$, moderate capacity for $\mathrm{Zn}(0.0000022$ $\mathrm{mg} \cdot \mathrm{g}^{-1}$ ) and lowest sorption capacity for $\mathrm{Cu}$ (Fig. 5a). Same, the highest and moderate sorbents capacity value for carwash effluents (Fig. 5b) were observed for $\mathrm{Cu}\left(0.0000012 \mathrm{mg} \cdot \mathrm{g}^{-1}\right)$ and $\mathrm{Zn}\left(0.0000005 \mathrm{mg} \cdot \mathrm{g}^{-1}\right)$ comparatively. Such type of linearity in the sorption profile of sorbent may leads to Henry's region existence [19].

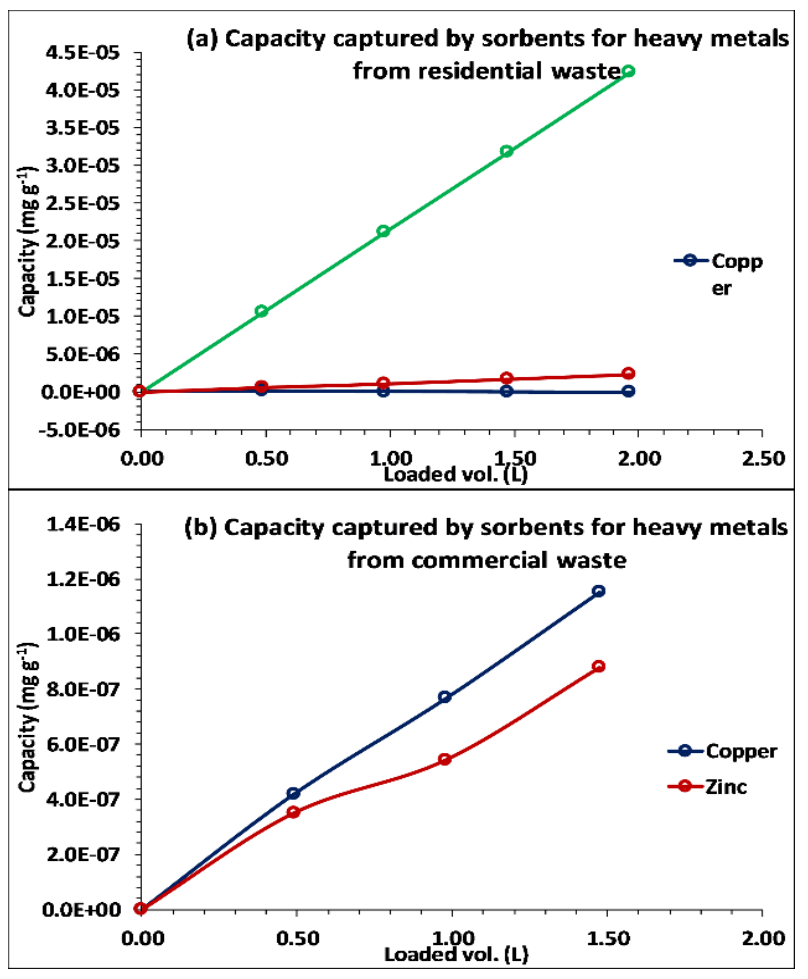

Fig. 5. Adsorption Capacity Profile of Sorbent Used for Removal of Heavy Metals.

\section{CONCLUSIONS}

The untreated and discharged domestic-waste water and carwash liquid effluents were passed for the adsorption of heavy metals using fly ash and sawdust as adsorbent materials. Overall, the sorbents used, have significantly strong removal efficiency for lead, moderate for zinc, and low for copper. The partition co-efficient and sorption capacity profile of the sorbents indicated the existence of isotherm Type-III. However, the retrograde region and Henry's region existence suggested to upload more liquid volume for the full-scale breakthrough profile of isotherm. Furthermore, the sorbent showed a prominent pattern for removal of heavy metals from domestic effluent as compared to commercial liquid waste. 


\section{ACKNOWLEDGMENT}

This study supported by the Higher Education Commission of Pakistan for Strat Research grant Program-R\&D Division (212364/SRGP/R\&D/HEC2019)

\section{REFERENCES}

[1] Eawag. (2018, November 29). Department Sanitation, Water and Solid Waste for Development. Available: https://www.eawag.ch/en/department/sandec/publicat ions/compendium/

[2] S. Khan, Q. Cao, Y. Zheng, Y. Huang, and Y. Zhu, "Health risks of heavy metals in contaminated soils and food crops irrigated with wastewater in Beijing, China," Environmental pollution, vol. 152, pp. 686692, 2008.

[3] UN. (2018, November 28). Untreated wastewater-a growing danger. Available: https://www.unenvironment.org/news-andstories/story/untreated-wastewater-growing-danger

[4] Wikipedia. (2018, November 28). Wastewaster. Available:

https://en.m.wikipedia.org/wiki/Wastewater\#cite_not e-4

[5] Worldometer. (2018, November 28). Pakistan population. Available: http://www.worldometers.info/worldpopulation/pakistan-population/

[6] J. H. Ensink, T. Mahmood, W. Van der Hoek, L. Raschid-Sally, and F. P. Amerasinghe, "A nationwide assessment of wastewater use in Pakistan: An obscure activity or a vitally important one?," Water policy, vol. 6, pp. 197-206, 2004.

[7] g. WHO, Edition, Fourth, "Guidelines for drinkingwater quality," WHO chronicle, vol. 38, pp. 104-8, 2011.

[8] H. M. Zwain, M. Vakili, and I. Dahlan, "Waste material adsorbents for zinc removal from wastewater: a comprehensive review," International Journal of Chemical Engineering, vol. 2014, 2014.

[9] B. Tyagi, C. D. Chudasama, and R. V. Jasra, "Determination of structural modification in acid activated montmorillonite clay by FT-IR spectroscopy," Spectrochimica Acta Part A: Molecular and Biomolecular Spectroscopy, vol. 64, pp. 273-278, 2006.

[10] D. News. (2018, November 30). World Water Day: Water shortage in Quetta poses serious challenges for the people. Available: https://dunyanews.tv/en/Pakistan/432322-WorldWater-Day-Water-shortage-in-Quetta-poses-seriouschallenges-for-t

[11] Wikipedia. (2018, November 29). Quetta. Available: https://en.wikipedia.org/wiki/Quetta\#cite_noteDISTRICT_WISE_CENSUS_RESULTS_CENSUS_ 2017-6

[12] Z. Kakar, S. M. Shah, and M. A. Khan, "Scarcity of water resources in rural area of Quetta District; challenges and preparedness," in IOP Conference
Series: Materials Science and Engineering, 2018, p. 012013.

[13] G. McMullan, C. Meehan, A. Conneely, N. Kirby, T. Robinson, P. Nigam, et al., "Microbial decolourisation and degradation of textile dyes," Applied microbiology and biotechnology, vol. 56, pp. 81-87, 2001.

[14] H. A. Maitlo, J. H. Kim, K.-H. Kim, J. Y. Park, and A. Khan, "Metal-air fuel cell electrocoagulation techniques for the treatment of arsenic in water," Journal of Cleaner Production, vol. 207, pp. 67-84, 2019.

[15] A. Khan, J. E. Szulejko, K.-H. Kim, P. Sammadar, S. S. Lee, X. Yang, et al., "A comparison of figure of merit (FOM) for various materials in adsorptive removal of benzene under ambient temperature and pressure," Environmental research, vol. 168, pp. 96108, 2019.

[16] H. A. Maitlo, K.-H. Kim, A. Khan, J. E. Szulejko, J. C. Kim, H. N. Song, et al., "Competitive adsorption of gaseous aromatic hydrocarbons in a binary mixture on nanoporous covalent organic polymers at various partial pressures," Environmental research, vol. 173, pp. 1-11, 2019.

[17] A. Khan, J. E. Szulejko, P. Samaddar, K.-H. Kim, B. Liu, H. A. Maitlo, et al., "The potential of biochar as sorptive media for removal of hazardous benzene in air," Chemical Engineering Journal, vol. 361, pp. 1576-1585, 2019.

[18] S. Lowell and J. Shields, "Adsorption isotherms Chapter in: Powder Surface Area and Porosity," ed: Springer: Dordrecht, 1984.

[19] A. Khan, J. E. Szulejko, P. Samaddar, K.-H. Kim, W. Eom, S. B. Ambade, et al., "The effect of diverse metal oxides in graphene composites on the adsorption isotherm of gaseous benzene," Environmental research, vol. 172, pp. 367-374, 2019.

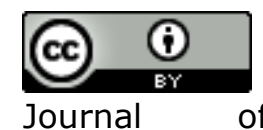

Applied and Emerging Sciences by BUITEMS is licensed under a Creative Commons Attribution 4.0 International License. 